Non-refereed Papers, Images, Reviews, Interviews

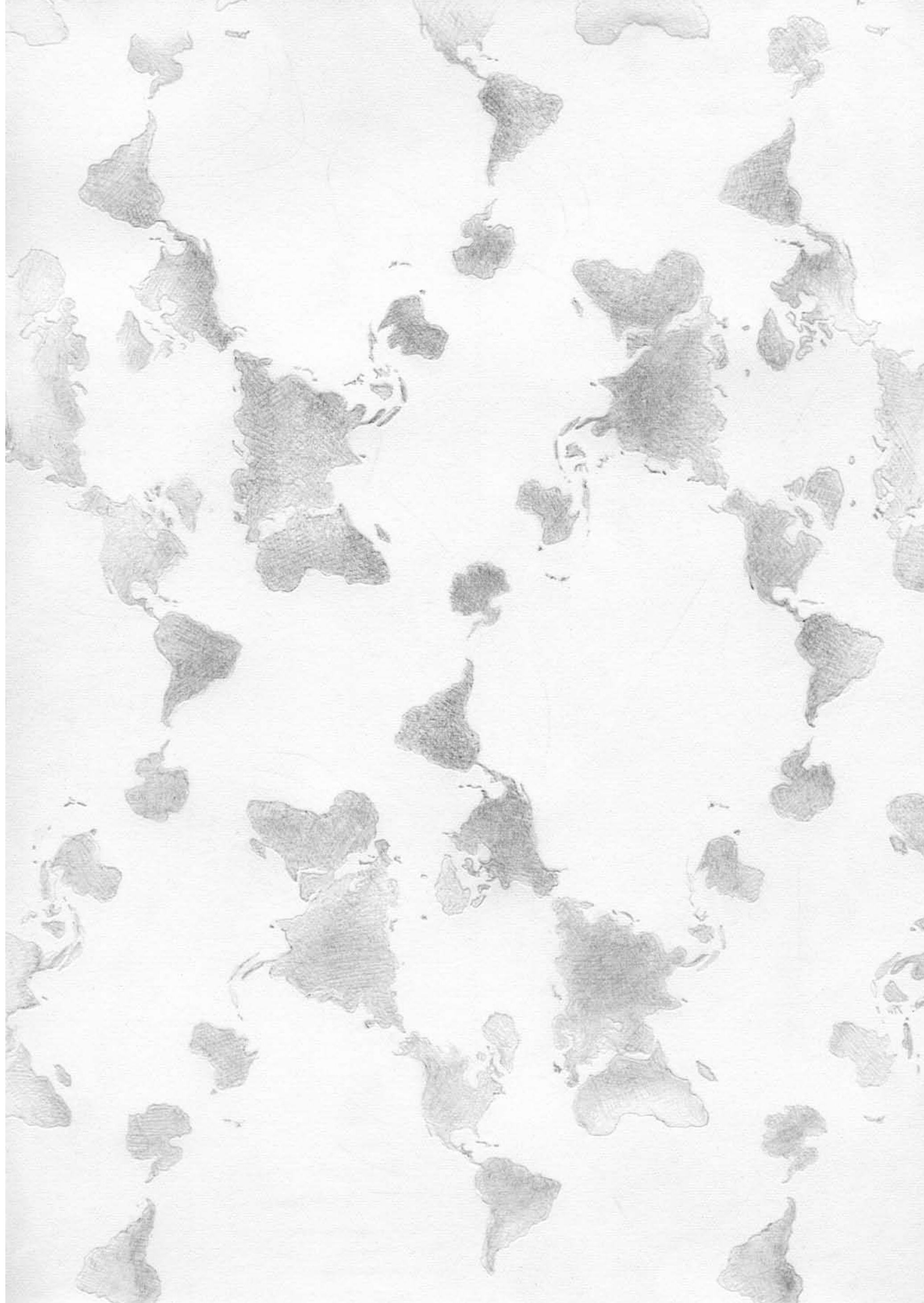




\section{Pattern Recognition}

Ruth Watson, Erased graphite on paper, 2008 (p. 75)

\section{Serendipity:}

Between Making a Magazine and Writing History

\author{
Justine Clark
}

How does architectural history engage with serendipitous events, with a chance encounter that is put to use in the practice or making of something, but which leaves no overt archival record? Serendipity, incident and accident are involved, to some extent, in every act of making - whether the product is a magazine, a building or a historical account/interpretation. But can the processes and practices of architectural history respond to the incidental, to the unwritten and the unarchived? Or is this outside history's frame of reference? Does history only deal with its subject matter in terms of events that leave overt physical, 'authoritative' traces? (What of oral history?)

This paper considers these questions. It originated in an invitation to "critique the practice of architectural history from my perspective as editor of Architecture Australia" for a conference of architectural historians (for Beynon \& de Jong, 2008). So, it is not the outcome of long hours of concentrated and considered research. Rather, it is the distillation of some ideas I have been mulling for a while, usually in a state of distraction, as I go about the everyday business of making a magazine. It is an attempt to bring these thoughts to bear on the topic of architectural history.

Architecture Australia is the journal of record of Australian architecture, and the latest in a direct line of publication that stretches back to $1904{ }^{1}$ As such, it is a the nificant resore nificat re day-to-day makg of he circumstances, serendipitous and otherwise, that leave few if any archival traces.
Nonetheless, the outcome of all these decisions is generally read as a definitive'. What might this mean for the magazine as a historical source? Acknowledging the role of serendipity does not necessarily undermine the 'authority' of the publication, but it does bring into question those historical accounts that are framed solely in terms of direct and apparently straightforward influence and intent.

I am not an architectural historian, but I have produced some architectural history, most notably Looking for the Local: Architecture and the New Zealand Modern which was co-authored with Paul Walker and published in 2000. As part of the research for this, I spent quite some time trawling through old issues of architectural journals and magazines, so I have some awareness of the role of publications such as Architecture Australia in the writing of history. More than this, the knowledge gained through this earlier work has had a valuable influence on my current role as editor of Architecture Australia It has provided a sto on my particulo

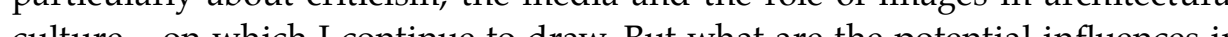
the other direction? Does the messy, quotidian activity of editing a magazine
L. For a short history of the magazine and its predecessors, see the sequence of (2004): Hogben (2004); Boddy 2004); The Editors (2004); and Hogben 
that is also a 'journal of record' have the potential to affect the way one might practise history?

This paper reflects on the messiness of making and the processes of writing architectural history, on the seductiveness for the historian of pinning down and fixing intention and influence, on the impact of apparently slight, incidental events, on what is left off the historical record, and whether this matters.

My interest in the conjunction of the messiness of production and the construction of the historical record is paty a reacion to of the magazin it. These seem to offer quite fixed accounts - put rather crudely, they might go: "in 19 somethingor-other so-and-so was president of the RAIA, his colleagues were published in the institute's magazine, therefore he must have exerted some influence on the content of the magazine". Now, this may have been the case, but it strikes me as a rather simplistic account of influence. In my experience, influence is rather less direct; power is exercised rather more subtly. Decisions about what to publish are the result of a more complicated and less overt set of circumstances, and the president and other RAIA officials have no direct input into what is published in any particular issue. This may have been different in the past, nonetheless I am sure that the magazine was still the outcome of complicated, in stances as well as highly considered policies and strategies.

Let me give an example. In May this year, Architecture Australia published a review of Ashton Ragoatt McDougall's Albury Cultural Centre (Peacock, 2008). In McDougall, director of ARM and member of the project team, is also the char of the RAIA Advisia ore ARM a to menber of the RAIA National Council. For a future historian looking to join the dots, the exercise of influence might seem obvious. However, the means by which the project came to be reviewed are in fact quite different. McDougal had indeed mentioned the project to me some years earlier when ARM won the commission, but I was made aware of its completion, and of its quality, in a quite different way. Over the course of two months in late 2007, I received three phone calls from quite different people, all of whose judgment I respect, each saying something like, "I am in Albury and I have just seen a very interesting building - you should publish it" Three unsolicited phone calls about a project is three more than I usually get, and it was in a regional town a location that is undere is uncer good idea. The reasons for doing so have left no archival trace. Does that matter?
Probably not.

I am not suggesting that future historians should or will care about how that building came to be published. But I am suggesting that the writers of history need to beware of the temptations of joining the dots and to be mindful of the seduction of apparently easy chains of influence and stories of intent.

Putting together any issue of a magazine involves a lot of planning, consideration and hard work - and an element of chance. No matter the intent of the editorial team, there is always a degree of serendipity at play, and the results are often the better for it. As with making anything, it is partly a matter of seeing how to take advantage of unintentional but fortuitous events, of recognizing possibilities and finding a way to make something of them.
No issue is made in an ideal environment. There is never a moment of quiet when all possible content is laid out before me, allowing a singular moment of informed decision about the content of a particular issue. Rather any issue is commissioned over time, with some decisions influenced by earlier ones, and things being revised and reconsidered as we go. An issue of a magazine is not a book. It is an iterative, cumulative thing, which makes sense over a sequence of issues, as well as within any particular issue.

Any issue of the magazine is always also slightly beyond my control. I collect a series of projects that I think will make sense together; I commission intelligent and thoughtful reviewers who will have something productive to say. Then a reviewer writes about projects in an unexpected way, and suddenly new connections are made within the content of an issue. The final photographs and drawings come in, and things change again: some images are particularly striking others are small files and cannot be used that big on the page. The designer sees an opportunity we hadn't thought of. Another ad booking comes in and I have to reduce something by a page. The baluce shifts again. The result is usually a network of projec a par ticular theme or type.

In the pages of the magazine quite different buildings rub against each other and maybe generate some sparks in the mind of the reader, who brings further interests and interpretations to bear on the content. Recognizing that the magazine as an object always exceeds the intent of the editorial team is important. It does not mean that one throws one's hands in the air and relinquishes responsibility but it does remind us that larger things are always at play than the intent of any particular individual or group of individuals. The magazine is a produc of the culture in which it is made, and editors, authors and architects are al cultural agents.

In making the magazine, I am also quite conscious of its role as journal of record and as future resource. I am quite aware that publishing a project is one important way of making it available for discussion in the architectural community, and that this is one first step in the consensual, communal creation of the canon. ${ }^{2}$ However, this consciousness of the role of the magazine in history also manifests itself in many small and pragmatic ways - for example, we put a great deal of are all reproduced th are all repreduch publication from others in Australia.

So, might we construct historical accounts that acknowledge or engage with serendipity and the contingent, with objects that cannot be understood only in terms of intent? Would this be useful? I believe these questions are relevant partly because they are at stake to some extent in all the objects that become the subjects and the sources of architectural history, not just in magazines.

The process of producing a magazine has parallels in the way other objects are made - most obviously buildings - and in the production of history itself. In making and telling coherent stories, history often tends to smooth over the messiness of the everyday. In some ways this is a necessary effect, but wrinkles can also be revealing. It might be useful for historians to remember the contingent nature of their own productions. How do their research projects come about? Which one
Juan Pablo Bonta's account of canon compelling. See Bonta (1979). 


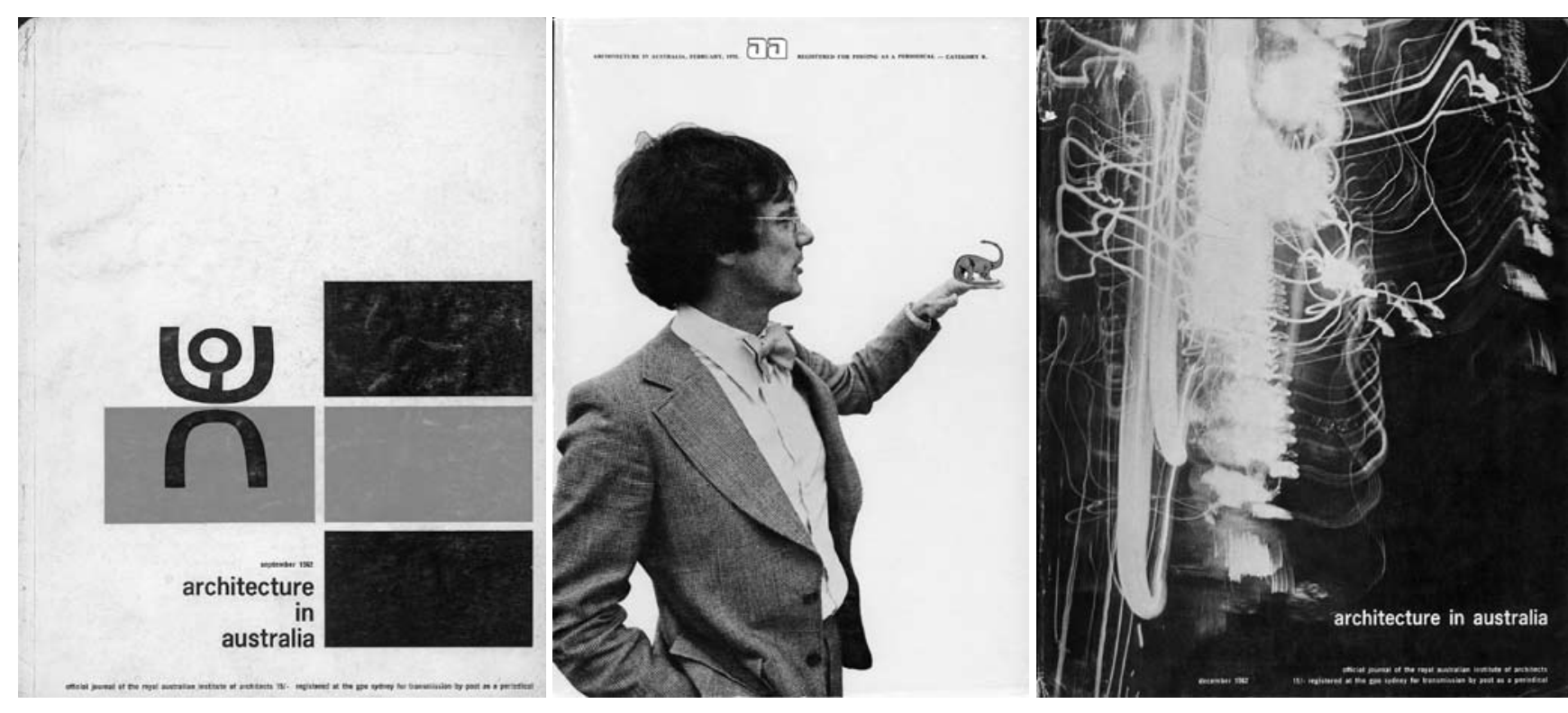

are realized, and for what reasons? Which ones languish? Which ones make through the obscure workings of the Australian Research Council (and why!)? How does a research project proceed? What of serendipity? How might reflecting on this affect the way in which one practises history?

\section{The Seduction of the Archive}

The archive is very seductive - there are the facts, just waiting to be dug up and strung together into stories. Written down, in black lines on white paper, these facts appear incontrovertible, apparently objective. Memory, by contrast, is unreliable; accounts are skewed to suit the agenda and interests of the teller. But of course the archive also provides a skewed account simply by virtue of what of con the the ar what is incluce and whe on gender, class and race, on those we werstoric record and how their stories might be retrieved. This work is very importan but what also interests me are the more incidental events by which one debate or thought is recorded, and thereby made available to the future historian, and one is not. And with all the facts embedded in the archive, waiting to be 'found' and interpreted, what of those events that leave only tiny traces?

One response to this dilemma is to simply try to record more and more, to keep filling in the gaps, to accumulate ever more detailed facts, to tell fuller and fulle stories, to record more and more oral history.

One of my favourite pieces of history writing that fills a gap using personal knowledge is an essay published by Reyner Banham in 1968. "The Revenge of the Picturesque" outlines a debate around modernism in postwar London which was influential, but left only slight traces in the printed record - in gossip columns, letters to the editor and so on. Banham uses his knowledge and recollections to draw these slight traces together. He begins, in his inimitable way:

Those of my generation who interrupted their architectural training in order to fight a war to make the world safe for the Modern Movement, tended to resume their studies after demobilization with sentiments of betrayal and abandonment. Two of the leading oracles of Modern Architecture appeared to have thrown principle to the wind and espoused the most debased English habits of comprome and sentimentality. (Banham, 1968: 265)
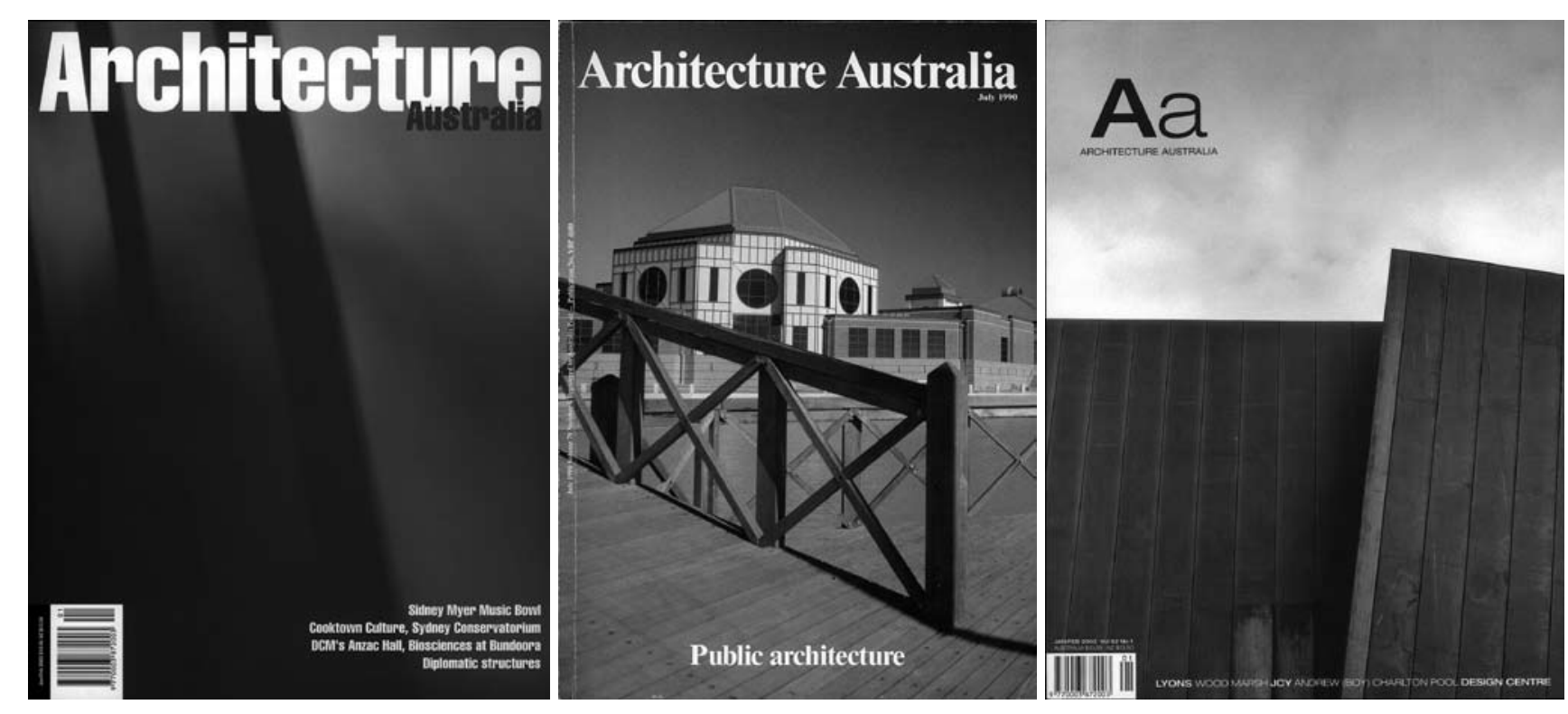

(He is talking of J. M. Richards and Nikolaus Pevsner). He continues,

So, combat was joined between a barely middle-aged architectural 'Establishment' armed with a major magazine, and a generation of battle-hardened and unusually mature students.... But the student generation were without much means of public expression .... and little of the polemic is visible in print. (Banham, 1968: 265-66)

Banham goes on to give a detailed, amusing account of the polemic through the slight traces they left in print, concluding by pointing out that it all ended with the total "triumph of the unacknowledged Picturesqueness of the Picturesque's avowed enemies" (Banham, 1968: 273). Like most of Banham's writing, this is a compelling and engaging essay. And it clearly makes the point that conversaions and a debes that have significant effects on tural cultures do not always leave much of a record, even when carried out by influential figures.

But filling in the gaps can also be a very dull exercise, leading to some very dul history. The model of the ever-expanding canon is not always the most interesting or useful way to produce history. And the gaps can never all be filled.

\section{The Incidental and New Zealand Architectural History}

But the gaps themselves might be interesting. This is an important point in this part of the world where so much architectural history goes unrecorded, and where canons seem to be built on quite ephemeral ground.

Indeed, I would suggest that architectural historians working in Australia and New Zealand might in fact be quite well equipped to deal with the questions I have raised, precisely because of the elusive nature of the archive and the printed record, and the need to be clever with the material one draws on to practise his-

I would like to speculate further on this, particularly in relation to New Zealand historical practices. These speculations are not based in considered analy sis - I have not had time to systematically survey the proceedings of previous SAHANZ conferences, or the back isues of Fabrications. Rather they come out of the SAHA strand of New Zealand architectural history writing. As I reflected on the ideas above through the lens of Arclitecture Austring it occus bility offers quite some opportunity for thinking inventively about the practice 
of history in relation to the serendipitous. So, my experiences here in Australia have sent me back to thinking about New Zealand. (But surely this is one of the benefits of SAHANZ)

This particular sensibility, which I think pervades one strand of New Zealand architectural history, is an interest in the minor, or the 'slight', and what it might offer. This is not an interest in simply adding more and more facts to the historical record, in constantly expanding the canon. Rather, it is an approach to hiscal record, in constantly expanding the canon. Rather, it is an approach to his-
tory predicated on what might be called the 'glance'. On looking awry, on using apparently minor details to offer new vantage points, from which to construct new interpretations and tell other stories, to illuminate issues that might otherwise go unnoticed. To my knowledge, this has not been clearly articulated as particular methodology, rather it has simply built up over the years. But it seem to offer some opportunities for dealing with 'stuff' on the edges of the historic record - a way of picking up the most minor trace, and running with it. And once you start looking from an odd angle, it is amazing what you find.

This approach is not restricted to New Zealand material. I recall a paper presented by Sean Flanagan at SAHANZ in 2002. This concerned the house for Dr Christ, described as “an uninvited guest at one of Modernism's most prestigious gatherings" (Flanagan, 2002: 58): that is the Weissenhofsiedlung The house left only tiny traces in the hist.

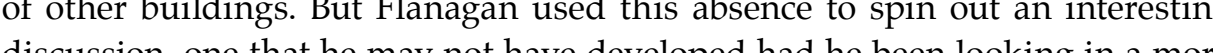
king in a more straightforward way.

This sensibility also influenced Looking for the Local, which used the story of an earlier book that never happened to unravel certain mythologies in New Zealand architecture. Indeed, writing a book about a book that didn't go ahead seems like a particularly New Zealand thing to do! I hope you will indulge me if I use this as an example.

Part of writing that book involved collecting stray elements floating on the surface of all kinds of architectural commentaries. These small traces indexed debates and discussions that had been influential but left no strong or clea historical record.

One telling example was the string of slight references around the idea of the 'straightforward'. Like the polemic outlined by Banham, this was an important idea, but it only left small traces. Coincidentally it also involved Nikolaus Pevsner in debate with younger architects, but without other famous players.

Pevsner was one of the few international critics to visit New Zealand and comment on its architecture postwar. ${ }^{3} \mathrm{He}$ did so in two radio talks; in "Commonwealth 1", a special issue of the Architectural Review on the architecture of the Dominions; and in a talk to the Royal Commonwealth Society (Pevsner, 1958a; Pevsner, 1958b; New Zealand, 1959: 206). In each of these he refers obliquely to a conversation with architect Bill Toomath about timber detailing. He tells the story differently on each occasion, recasting it for various audiences. Sometime Pevsner allows that there may be some potential in such crude detailing - "Maybe he was right, maybe that robustness of detail which strikes me as a little raw will one day be a valid expression of the will one day" (Pevsne, 1958b; 4) - but in the anonymous piece for the Century architecture" (Pevser, 1958b: 4)-but the New Zenymous piece for the prestigion canon-making Architectural Review, he leaves no room for such possibility: lack of means is often apparent in the detailing, although a certain crudity is called straightforwardness and, at least by some of the most thoughtful young architects, set up as a new country feature in opposition to the old-men's fussiness at home. It sounds convincing at first, but California is not all that old, but it still manages to get its details right. (New Zealand, 1959: 206)

This generated a series of responses in New Zealand. In 1960 the New Zealand Listener reviewed the Review, disseminating the story to a wide local audience and claiming straightforwardness as a national trait (Seen from a Distance, 1960: 7). ${ }^{4}$ The director of Auckland Art Gallery, Peter Tomory, did likewise, writing, "A colonial heritage begets directness, bluntness in fact, a kind of colonial Brutalism which provides a strong tonic to the too-sugared spirit of European sophistication" (Tomory, 1961: 76). Not every local commentator agreed. In a piece called "The Wild Colonial Boys", Comment deplored the cultural nihilism of the Listener (Wild Colonial Boys, 1960: 10).

Tangential references to this conversation continued to appear as arguments for the straightforward were made and remade. ${ }^{5}$ It reverberates as late as 1993 when Leonard Bell, writing about the role of the primitive in New Zealand art, quotes Tomory and excises all connection to architecture (Bell, 1993: 111). When each reference is read in isolation they are hardly noticed. However, when collected together they can be recognized as the strange echo of an incidental conversation about a post propping up a carportin Lower Hutt The bizarre yet po effect of apparently incidental material becomes apparent.

It might be said that this scraping together of slight references and tangential asides is another kind of join-the-dots. However, I would argue the difference is we to which these references are put, and the way they are understood. They are not treated as a string of facts to determine influence, or intent nor as the building blocks of the canon. Rather they are understood as indices of architectural debates and discussion which might be worth interpretation. Stray sentences, half-developed ideas in building reviews, historical overviews and statements of intent might be read as the shadows, scratches and traces left by numerous events and discussions which leave no clear concrete archival account, but were nonetheless influential. What new critical and historical possibilities might open up if we develop these other ways of understanding archival traces - for example, in terms of indexicality? Might this lead to other kinds of productive architectural encounters?

This might seem like a long way from where I started - from serendipity and the everyday activity of editing Architecture Australia. However, I think that the idea of reading archival traces as indices has a lot of potential for negotiating the complex array of issues with which I began. It allows you to work in the space between intention and incident, between serendipity and authority, between economics and idea like Architecture Austh like Architcetue Australla. This is the space that I work in daily, and in which I am also interested in terms of the practice of history. The index allows you to negotiate these spaces because although it is a sign that is read as a mark caused by an action, it is also, if we follow Umberto Eco, a culturally produced effect. What is it to think of the stuff from which we make history in these terms? 


\section{References}

Banham, R. (1968). The Revenge of the Picturesque: English Architectural Polemics 1945-1965. In J. Summerson (Ed.), Concerning Architecture (pp. 265-73). London: Allen \& Lane.

Bell, Leonard. (1993). Landfall, the Primitive, and the Visual Arts in the 1950s. Landfall, 1 (1 [new series]), 106-13.

Beynon, D., \& de Jong, U. (Eds.) (2008). History in Practice: $25^{\text {th }}$ International Conference of the Society of Architectural Historians, Australia and New Zealand. Geelong, Vic: SAHANZ.

Boddy, A. (2004). Photography and Architecture. Architecture Australia, 93(4), 20-21.

Bonta, J. P. (1979). Architecture and its Interpretation: A Study of Expressive Systems in Architecture. London: Lund Humphries.

Clark, J. \& Walker, P. (2000). Looking for the Local: Architecture and the New Zealand Modern. Wellington: Victoria University Press.

The Editors. (2004). Architecture Australia, 93(5), 23-27.

Flanagan, S. (2002). The Weissenhofsiedlung and the House for Dr Christ. In J. Macarthur \& A. Moulis (Eds.), Additions to Architectural History: 19 th Annual Conference of the Society of Architectural Historians, Australia and New Zealand. Brisbane: SAHANZ.

Goad, P. (2004). One Hundred Years of Discourse. Architecture Australia, 93(1), 18-26.

Hogben, P. (2004). One Hundred Years of Advertising. Architecture Australia, 93(2), 20-23.

Hogben, P. \& Stead, N. (2004). Rhetoric and Tone. Architecture Australia, 93(6), 26-30.

New Zealand (1959). Architectural Review, 126(752), 206.

Peacock, D. (2008). Albury Cultural Centre. Architecture Australia, 97(3), 58-65.

Pevsner, N. (1958a). The Ingratiating Chaos: Impressions of New Zealand. Listener (UK) 60(November 20), 825-27. Extracts published in Journal of the NZIA, 26(2), 42-43.

Pevsner, N. (1958b). New Architecture and New Art. New Zealand Listener, 40(1010), 4. Republished in Journal of the NZIA, 25(10), 261-85.

Seen from a Distance: London Journal Looks at NZ Architecture. (1960). New Zealand Listener, 42(1067), 6-7.

Sheppard, N. \& J. (1961). Domestic Architecture in New Zealand. Architectural Design, 31(October), 471-74.

Skinner, R. (1996). Nikki Down Under: Impressions of Pevsner in New Zealand. In P. Goad \& J. Willis (Eds.), Loyalty and Disloyalty in the Architecture of the British Empire and Commonwealth: Selected Papers from the Thirteenth Annual Conference of the Society of Architectural Historians, Australia and New Zealand, Auckland, New Zealand, 1996 (pp. 102-10). Melbourne: SAHANZ / University of Melbourne.

Tomory, P. (1961). The Visual Arts. In K. Sinclair (Ed.), Distance Looks our Way: The Effect of Remoteness on New Zealand (pp. 63-78). Auckland: Paul's Book Arcade for the University of Auckland.

The Wild Colonial Boys (1960). Comment, (Spring), 10. 